\title{
EXTRACTION, PURIFICATION AND BIOCHEMICAL CHARACTERIZATION OF A PEROXIDASE FROM Copaifera langsdorffii LEAVES
}

Hermelinda Penha Freire Maciel e Cibele Marli Cação Paiva Gouvêa*

Departamento de Ciências Biológicas, Universidade Federal de Alfenas, Rua Grabriel Monteiro da Silva, 714, 37130-000 Alfenas - MG, Brasil

Marcos Toyama, Marcus Smolka e Sergio Marangoni

Departamento de Bioquímica, Instituto de Biologia, Universidade Estadual de Campinas, 13100-000 Campinas - SP, Brasil Gláucia Maria Pastore

Departamento de Ciência de Alimentos, Faculdade de Engenharia de Alimentos, Universidade Estadual de Campinas, 13100-000 Campinas - SP, Brasil

Recebido em 3/1/06; aceito em 12/1/07; publicado na web em 24/7/07

\begin{abstract}
EXTRACTION, PURIFICATION AND BIOCHEMICAL CHARACTERIZATION OF A PEROXIDASE FROM Copaifera langsdorffii LEAVES. The aim of this work is to obtain, purify and characterize biochemically a peroxidase from Copaifera langsdorffii leaves (COP). COP was obtained by acetone precipitation followed by ion-exchange chromatography. Purification yielded $3.5 \%$ of peroxidase with the purification factor of 46.86 . The COP optimum $\mathrm{pH}$ is 6.0 and the temperature is $35{ }^{\circ} \mathrm{C}$. COP was stable in the pH range of 4.5 to 9.3 and at temperatures below $50.0^{\circ} \mathrm{C}$. The apparent Michaelis-Menten constants (Km) for guaiacol and $\mathrm{H}_{2} \mathrm{O}_{2}$ were $0.04 \mathrm{mM}$ and $0.39 \mathrm{mM}$ respectively. Enzyme turnover was $0.075 \mathrm{~s}^{-1}$ for guaiacol and $0.28 \mathrm{~s}^{-1}$ for hydrogen peroxide. Copaifera langsdorffii leaves showed to be a rich source of active peroxidase (COP) during the whole year. COP could replace HRP, the most used peroxidase, in analytical determinations and treatment of industrial effluents at low cost.
\end{abstract}

Keywords: Copaifera langsdorffii; peroxidase; vegetal extract.

\section{INTRODUCTION}

Peroxidases are heme containing enzymes that oxidize a variety of proton donor compounds such as diphenols, polyphenols aminophenols, among others, in the presence of hydrogen peroxide ${ }^{1}$. Peroxidases represent a group of enzymes widely distributed in the plant kingdom ${ }^{2}$ and has been extracted from several plants including horseradish (Armoracia rusticana), peach (Prunus persica), yam (Alocasia macrorhiza), manioc (Manihot utilissima), artichoke (Cynara scolymus L.), sweet potato (Ipomoea batatas ex L., Lam.), turnip (Brassica campestre rapifera), zucchini (Cucurbita pepo) and others ${ }^{3-6}$. For vegetables and fruits the various types of isoperoxidases, including the anionic and cationic types with low and high isoelectric point values respectively, can be extracted as both soluble and membrane bound isoforms ${ }^{7}$.

Plant peroxidases are known to be comprised of a range of isoenzymes differing in number from one vegetable source to another and have been observed to differ with respect to thermal stability, optimum $\mathrm{pH}$, substrate specificity, amino acid composition and their physiological roles in the plant tissues ${ }^{8,9}$. The catalytic characteristics and thermal properties of the individual isoenzymes have received considerable attention due to their thermostability and ability to recover their enzymatic activity after partial heat-inactivation and hence their potential effect on food quality ${ }^{10}$. Peroxidases from a number of sources lose activity on heating following biphasic-linear first-order kinetics. Such behavior has been attributed either to isoenzymes of different heat stabilities ${ }^{11}$, or the conversion of the native enzyme to new isoforms with enhanced stability ${ }^{12,13}$.

In biotechnology and associated research areas (enzymology, biochemistry, medicine, genetics, physiology, histo- and cytochemistry),

*e-mail: cibelegouvea@hotmail.com peroxidases have conquered a prominent position ${ }^{14}$ and it remains the major enzyme used to evaluate the heat processing of vegetables ${ }^{7}$. The investigation of this enzyme may be of interest, not only for its negative effects on color and flavor, degradations of pigments and nutritional value, but also for its positive effects in food ${ }^{15,16}$.

Peroxidase is used for developing reliable methods of the determination of hydrogen peroxide, which is of great importance in both the biological and industrial fields ${ }^{17}$. This enzyme can still be employed in the determination of lipid peroxidation in cell membranes ${ }^{18}$ and in meat food products ${ }^{19-21}$. The application of plant and microorganism peroxidase to catalyze the polymerization and precipitation of aqueous phenols and decolorization of bleach plant effluent by hydrogen peroxide is potentially promising, because those peroxidases are less expensive than horseradish peroxidase, which has been the focus of most wastewater research ${ }^{22-24}$. The use of peroxidases in the construction of biosensors and other enzymatic procedures, immobilized in various matrixes or peroxidase rich microorganisms in modern organic synthesis are important emerging applications of this enzyme $e^{3,14,25-33}$.

Despite the variety of plant peroxidase sources, there is no previous work on peroxidase from $C$. langsdorffii Desf. leaves (Leguminosae). This plant is popularly known as "copaíba", and is a large tree that grows abundantly through out Brazil, mainly in the Central region and Minas Gerais State ${ }^{34}$. The present investigation reports the isolation, purification and biochemical characterization of anionic peroxidase (COP) from Copaifera langsdorffii leaves.

\section{EXPERIMENTAL}

\section{Plant material}

Leaves of Copaifera langsdorffii were collected during the whole year from plants grown under native conditions at the 
Department of Botany of the State University of Campinas (UNICAMP), São Paulo, Brazil. The leaves were transported to the laboratory, washed and used for peroxidase extraction. The leaves were freshly used or stored at $8{ }^{\circ} \mathrm{C}$ up to 7 days. For the evaluation of peroxidase activity, the extract was immediately used or stored at $-18{ }^{\circ} \mathrm{C}$ up to three months.

\section{Crude extract preparation}

The leaves were homogenized in cold $\left(4^{\circ} \mathrm{C}\right) 50 \mathrm{mM}$ phosphate buffer $\mathrm{pH} 6.0$ (4 mL/g of leaves), in a domestic blender for $5 \mathrm{~min}$. The homogenate was rapidly filtered through six layers of cheesecloth and centrifuged at $11,000 \times \mathrm{g}$ for $15 \mathrm{~min}$ at $4{ }^{\circ} \mathrm{C}$. The supernatant was taken as the source of peroxidase, and the determination of activity was performed immediately ${ }^{35}$.

\section{Partial peroxidase purification}

Semi-purified peroxidase was obtained from the crude extract, which was homogenized with $65 \%$ pre-cooled acetone $\left(-18{ }^{\circ} \mathrm{C}\right)$. Using a burette the acetone was added slowly down the sides of the container held in an ice bath. After standing for 12 to $14 \mathrm{~h}$ at $4{ }^{\circ} \mathrm{C}$, the homogenate was centrifuged at $11,000 \mathrm{x} g$ for $15 \mathrm{~min}$ at $4{ }^{\circ} \mathrm{C}$. The supernatant was discarded, and the acetone powder was dried at a temperature of $10-15^{\circ} \mathrm{C}$ and used for the peroxidase assay and the estimation of protein content. The semi-purified peroxidase was stored at $-18{ }^{\circ} \mathrm{C}$ until use.

\section{Purification of the anionic peroxidase (COP)}

All purification steps were carried out at $15{ }^{\circ} \mathrm{C}$. The enzymatic fraction was obtained by a three-step purification procedure. The first step consisted of the crude extract preparation, followed by partial purification and finally the purification of the enzyme. An adequate amount of partial purified peroxidase was dissolved in 50 $\mathrm{mM}$ sodium phosphate buffer $\mathrm{pH}$ 6.0. The enzyme was then loaded on a DEAE-Sepharose column $(1 \mathrm{~mL})$ and eluted with a 0 to $0.5 \mathrm{M}$ $\mathrm{NaCl}$ linear gradient in $50 \mathrm{mM}$ sodium phosphate buffer $\mathrm{pH}$ 6.0, at a flow rate of $1.0 \mathrm{~mL} / \mathrm{min}$, in a FPLC System Pharmacia. The protein concentration of the fractions was routinely estimated by measuring the absorbance at $280 \mathrm{~nm}$ and the activity in each eluated fraction was determined in triplicate by measurement of the absorbance at $470 \mathrm{~nm}$ of tetraguaiacol $\left(\varepsilon=6.65 \times 10^{3} \mathrm{M}^{-1} \mathrm{~cm}^{-1}\right)^{36}$.

Active fractions from the DEAE-Sepharose column were pooled and dialyzed against deionized water, then concentrated by freeze drying and stored at $-20^{\circ} \mathrm{C}$ for use to the biochemical characterization.

\section{Protein electrophoresis}

The purified peroxidase was used for PAGE or SDS-PAGE in order to estimate the enzyme activity, MW (molecular weight) and purity. The sample preparation for native PAGE was performed according to Davis ${ }^{37}$, after dialysis overnight. Enzyme-substrate staining of the native PAGE gels was carried out using guaiacolhydrogen peroxide ${ }^{38}$. For SDS-PAGE the samples were boiled in the presence of sodium dodecyl sulfate (SDS) and 2mercaptoethanol and separated in a $12 \%$ gel according to Laemmli ${ }^{39}$. The proteins were stained with coomassie brilliant blue R-250. The standard molecular weight used were: phosphorylase b (94,000 Da), bovine serum albumin $(67,000 \mathrm{Da})$, ovalbumin $(43,000 \mathrm{Da})$, carbonic anhydrase (30,000 Da), soybean trypsin inhibitor $(20,100$ $\mathrm{Da})$, and a-lactoalbumin (14,400 Da).

\section{Isoelectric point determination}

Denaturing two-dimensional gel electrophoresis was used for determination of the isoelectric point of COP. Twenty $\mu \mathrm{g}$ of the purified protein were dissolved in $350 \mu \mathrm{L}$ of sample buffer containing $8 \mathrm{M}$ urea, $4 \%$ (w/v) CHAPS ([3-(3-cholamidopropyl) dimethylammonio]1-propane-sulfonate), 2\% (v/v) carrier ampholytes $\mathrm{pH} 3-10,70 \mathrm{mM}$ DTT (dithiothreitol) and $0.001 \%$ (w/v) bromophenol blue. Except for CHAPS, which was from Sigma, all reagents were from Amersham Biosciences. The sample was then loaded on IPG (Immobilized pH Gradient) strips with a non-linear separation range of $\mathrm{pH} 3-10$. After a $10 \mathrm{~h}$ rehydration, isoelectric focusing was carried out at $20^{\circ} \mathrm{C}$ for $1 \mathrm{~h}$ at $500 \mathrm{~V}$, for an additional hour at $1000 \mathrm{~V}$ and finally for $10 \mathrm{~h}$ at 8000 $\mathrm{V}$ in an IPGphor apparatus (Amersham Biosciences), maintaining a limiting current of $50 \mu \mathrm{A}$ per strip. After the run, the strip was soaked for $10 \mathrm{~min}$ in a solution containing $50 \mu \mathrm{M}$ Tris- $\mathrm{HCl}(\mathrm{pH} 6.8), 6 \mathrm{M}$ urea, 30\% (v/v) glycerol, $2 \%(\mathrm{w} / \mathrm{v})$ SDS and 2\% (w/v) DTT, and for an additional $10 \mathrm{~min}$ in the same solution containing $2.5 \%(\mathrm{w} / \mathrm{v})$ iodoacetamide instead of DTT. The second dimension electrophoresis (SDS-PAGE) was performed on an SE-600 system connected to a Multitemp II refrigerating system (both from Amersham Biosciences). After laying the strip on top of a $12.5 \%$ polyacrylamide gel and sealing it with agarose, electrophoresis was carried out for $1 \mathrm{~h}$ at $90 \mathrm{~V}$ at a constant current (30 mA per gel) applied until the dye front reached the lower end of the gel. Proteins were detected using standard coomassie blue staining and the isolectric point was determined using a calibrating curve supplied by the manufacturer.

\section{Molecular weight determination}

Gel filtration chromatography of adequate quantities of COP was performed on a HiPrep 16/60 Sephacryl S-200 column (internal diameter of $16 \mathrm{~mm}$, height of the packed gel bed of $60 \mathrm{~cm}$, giving a bed volume of $120 \mathrm{~mL}$ ), using blue dextran for the void volume determination and soybean trypsin inhibitor (20,100 Da); carbonic anhydrase $(30,000 \mathrm{Da})$; ovalbumin $(43,000 \mathrm{Da})$; bovine serum albumin $(67,000 \mathrm{Da})$; phosphorylase b (94,000 Da) as standards. The molecular weight of the peroxidase was calculated from a regression curve, where log of the molecular weights of the standards were plotted against the ratio of the elution volumes of the standards and the void volume of the column.

\section{Peroxidase activity and total protein determinations}

Peroxidase activity was determined in triplicate by measurement of the absorbance at $470 \mathrm{~nm}$ of tetraguaiacol $\left(\varepsilon=6.65 \times 10^{3} \mathrm{M}^{-1} \mathrm{~cm}^{-1}\right)^{36}$. Briefly, we used $1.5 \mathrm{~mL}$ of $1 \%$ guaiacol and $0.4 \mathrm{~mL}$ of $0.1 \mathrm{M}$ hydrogen peroxide in $50 \mathrm{mM}$ phosphate buffer $\mathrm{pH} 6.0$ at $35^{\circ} \mathrm{C}$ and the reaction was started by adding $0.1 \mathrm{~mL}$ of peroxidase solution. The peroxidase activity was measured while the reaction was at the initial rate (1.5$3.0 \mathrm{~min})$. One unit of activity was defined as the amount of enzyme that causes an increase of 0.001 absorbance per $\min ^{36}$. Total protein concentration was determined in triplicate, using bovine serum albumin as standard, according to Lowry et al. $^{40}$.

\section{Km and enzyme turnover determination}

Michaelis-Menten constant $(\mathrm{Km})$ and enzyme turnover $\left(\mathrm{E}_{\mathrm{t}}\right)$ for the COP substrates guaiacol and $\mathrm{H}_{2} \mathrm{O}_{2}$ were determined by incubating $0.1 \mathrm{~mL}$ of purified peroxidase with different concentrations of guaiacol and a fixed saturated concentration of $\mathrm{H}_{2} \mathrm{O}_{2}$ or vice-versa. The $\mathrm{Km}$ and $\mathrm{E}_{\mathrm{t}}$ values were determined from double reciprocal plots of enzyme activity and substrate 
concentration, using Grafit, Version 3.0, Erithacus Software ${ }^{41}$. The turnover number of an enzyme is a measure of the number of reaction processes, i.e. number of ES complexes that are converted to product, per enzyme molecule per unit time. This experiment was carried out at $35^{\circ} \mathrm{C}$.

\section{Analytical RP-HPLC of COP}

The COP was analyzed for homogeneity by RP-HPLC, on the U-Bondapack C18 column, preparative scale, $(0.78 \mathrm{~cm} \times 30 \mathrm{~cm})$. The peroxidase was dissolved in solution A, $0.1 \%$ TFA (trifluoroacetic acid) in water. After homogenization, the samples were clarified by high speed centrifugation at $11,000 \mathrm{x} g$ for $2 \mathrm{~min}$ and applied to the chromatographic column. The proteins were eluted using a linear gradient of $0-70 \%$ acetonitrile in solution A, at $0.48 \mathrm{~mL} / \mathrm{min}$ and freeze dried. The COP was eluted with a eluent volume of $11-17 \mathrm{~mL}$.

\section{Amino acid analysis and N-terminal sequence determination}

Amino acid analysis of COP was performed in duplicate with a PICO-TAG PTH amino acid (phenylthiohydantoin amino acid) analyzer. The COP was hydrolyzed in $6 \mathrm{~N} \mathrm{HCl}$ in the presence of $1 \%$ phenol for $24 \mathrm{~h}\left(106{ }^{\circ} \mathrm{C}\right)$ and derivate with PITC (phenyl isothiocyanate) before being injected in the column. Amino acids were eluted by using an acetonitrile linear concentration gradient in $50 \mathrm{mM}$ sodium acetate buffer. The identification and quantification of each amino acid were carried out using the PTH amino acid standard.

$\mathrm{N}$-terminal sequence analysis of COP was performed by automated Edman degradation using instrumentation protocols from Applied Biosystems. A model Procise of a gas-phase sequencer equipped with an online model $140 \mathrm{C}$ Microgradient Delivery System and model 785A UV detector was used. Sample amino acid identification was done by comparison of its retention times to the standard PTH amino acids.

\section{Stability and optimal temperature and pH determination}

COP stability, optimal temperature and $\mathrm{pH}$ were determined using factorial design experiments. The impact of $\mathrm{pH}$ and temperature on COP activity was measured by varying the $\mathrm{pH}$ and temperature according to the intervals proposed by the factorial analysis and the design of the experimental levels. Experiments were performed using different buffer species to achieve optimum $\mathrm{pH}$ and temperature conditions. The COP was incubated in buffer solutions with intervals of $\mathrm{pH}$ (3.7-9.7) and temperature $\left(7.7-92.3{ }^{\circ} \mathrm{C}\right)$, as proposed in the factorial analysis and design of experimental levels during 2, 4, 8, 16 and $24 \mathrm{~h}$. After that, the $\mathrm{COP}$ was transferred to $\mathrm{pH} 6.0$ at $35^{\circ} \mathrm{C}$, its activity was determined and compared to the activity of a same amount of enzyme that was not previously incubated at different $\mathrm{pH}$ and temperature. COP was considered stable when the activity of the incubated enzyme did not differ significantly $(p<0.05)$ from the activity of the non-incubated enzyme. The results were analyzed using the software Statistica.

\section{RESULTS AND DISCUSSION}

\section{Extraction and purification of the anionic peroxidase (COP)}

The optimum extraction buffer was found to be $50 \mathrm{mM}$ sodium phosphate buffer, pH 6,0. Other buffer systems as used by Jackson and Ricardo ${ }^{35}$ resulted in lower peroxidase activity per gram of $C$. langsdorffii leaves. The results of the purification of COP are shown in Table 1 . A $60.5 \%$ recovery of peroxidase activity was obtained by acetone precipitation.

Further purification was obtained by ion-exchange chromatography on a DEAE-Sepharose-FF column in FPLC, resulting in one peak eluted with a $0.2 \mathrm{M}$ salt $(\mathrm{NaCl})$ gradient (Figure 1). From this end-step in the purification, a final purification factor of 46.86 was obtained (Table 1), with a yield of $3.5 \%$

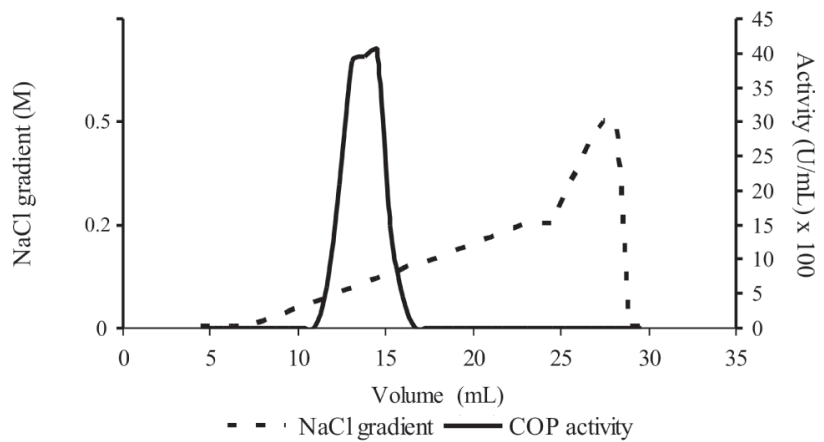

Figure 1. Anion exchange chromatography of COP on DEAE-Sepharose FFFPLC. Peroxidase activity was detected by oxidation of guaiacol with $\mathrm{H}_{2} \mathrm{O}_{2}$ at $470 \mathrm{~nm}$

\section{Electrophoresis, isoelectric point and molecular weight determination}

The soluble anionic fraction obtained from PAGE under nondenaturing conditions of the purified anionic peroxidase from $C$. langsdorffii, (COP) showed only one band detected in situ by a chromatogenic assay with guaiacol: hydrogen peroxide staining (Figure 2a) or with coomassie brilliant blue under denaturing conditions (Figure 2b).

The results indicate preservation of the enzyme activity, which is known to be adversely affected in purification procedures for the separation of peroxidase isoenzymes from plant extracts ${ }^{42}$. It is interesting to point out that the semi-purified enzyme showed a strong band in both electrophoresis systems, denaturing and nondenaturing, and high activity. Thus, the leaves of C. langsdorffii can be considered as a potential source of anionic peroxidase.

Homogeneity of the sample of COP was confirmed by analytical reversed-phase HPLC (Figure 3). The isoelectric point of the enzyme was determined to be 4.0 by bidimensional, isoelectric focusing electrophoresis. The molecular weight (MW) of the anionic peroxidase (COP) was estimated to be $59 \mathrm{kDa}$ by regression analysis. The results were in agreement with those reported by Civello et al..$^{43}$, for isoperoxidases from strawberry which exhibited MW of 58.1 and $65.5 \mathrm{kDa}$. Isoperoxidases do not differ significantly

Table 1. Purification of peroxidase from Copaifera langsdorffii leaves (COP)

\begin{tabular}{|c|c|c|c|c|c|c|c|}
\hline Fraction & Quantity & $\begin{array}{l}\text { Total activity } \\
\left(\mathrm{U} \times 10^{3}\right)\end{array}$ & $\begin{array}{l}\text { Activity } \\
(\mathrm{U} / \mathrm{mL})\end{array}$ & $\begin{array}{l}\text { Protein } \\
(\mu \mathrm{g} / \mathrm{mL})\end{array}$ & $\begin{array}{c}\text { Specific } \\
\text { Activity } U / \mu \mathrm{g}\end{array}$ & $\begin{array}{l}\text { Purification } \\
\text { factor }\end{array}$ & $\begin{array}{c}\text { Yield } \\
(\%)\end{array}$ \\
\hline Crude extract & $3900 \mathrm{~mL}$ & 268476 & 68,840 & 23,826 & 2.89 & 1.00 & 100.0 \\
\hline Acetone powder & $8 \mathrm{~g}$ & 333 & 41,580 & 2,190 & 18.98 & 6.57 & 60.5 \\
\hline DEAE Sepharose & $28 \mathrm{~mL}$ & 67 & 2,400 & 18 & 135.44 & 46.86 & 3.5 \\
\hline
\end{tabular}




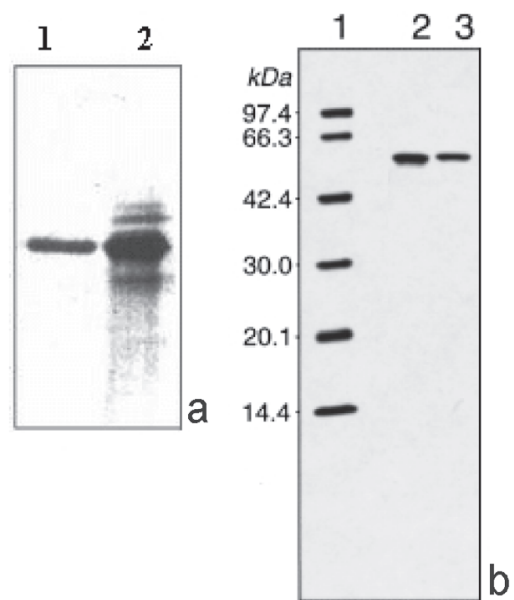

Figure 2. Electrophoresis of a peroxidase $(10 \mu \mathrm{g})$ from Copaifera langsdorffii leaves (COP): a, Native PAGE: (1) Purified, (2) Semi purified COP; $b$, SDSPAGE: (1) Molecular weight markers (kDa), (2) Semi- purified COP, (3) Purified COP

in size, with MW in the range from 40 to $60 \mathrm{kDa}$. Since the isoelectric points of the isoenzymes for a given species of plant vary considerably over a wide $\mathrm{pH}$ range, it is reasonable to expect that the isoenzymes differ substantially in amino acid content ${ }^{8}$.

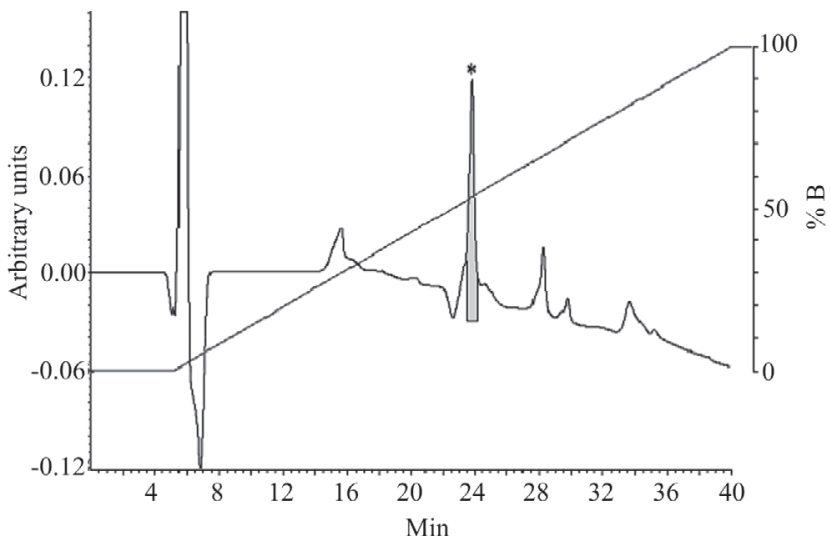

Figure 3. COP RP-HPLC. The purification was carried out in a linear gradient of $0-70 \%$ acetonitrile in $0.1 \%$ trifluoroacetic acid $(B)$ and the chromatography was monitored at $220 \mathrm{~nm}$. The asterisk indicates the purified protein.

\section{COP activity, total protein, $\mathrm{Km}$ and $\mathrm{E}_{\mathrm{t}}$ determinations}

The peroxidase activity in the samples decreased with purification, as well as the total protein content, but the specific activity increased (Table 1). Despite the decreased activity of COP, compared to the semi-purified enzyme, COP activity was higher than other sources of materials, for example, strawberry ${ }^{44}$, barley ${ }^{45}$, and leaves of Vitis pseudoreticulata ${ }^{46}$.

The kinetic parameters $\mathrm{Km}$ and $\mathrm{E}_{\mathrm{t}}$ were estimated in the system of guaiacol: hydrogen peroxide at the optimal temperature found to the enzyme that was $35^{\circ} \mathrm{C}$. The $\mathrm{Km}$ of the $\mathrm{COP}$ for guaiacol and $\mathrm{H}_{2} \mathrm{O}_{2}$ were $0.04 \mathrm{mM}$ and $0.39 \mathrm{mM}$ respectively. $\mathrm{E}_{\mathrm{t}}$ values were 0.075 $\mathrm{s}^{-1}$ for guaiacol and $0.28 \mathrm{~s}^{-1}$ for hydrogen peroxide. The COP presented higher substrate affinity and $\mathrm{E}_{\mathrm{t}}$ than other peroxidases previously reported. Holschuh ${ }^{47}$ reported a $\mathrm{Km}$ of $20.28 \mathrm{mM}$ and Vmax of 8,210 U/min for guaiacol, and for hydrogen peroxide a $\mathrm{Km}$ of $12.75 \mathrm{mM}$, and $\mathrm{Vmax}$ of 11,635 U/min for carambola anionic peroxidase.

\section{Amino acid analysis and N-terminal sequence determination}

An N-terminal micro-sequencing of 15 amino acid residues was obtained for the COP (Table 2). The amino acid sequence of COP and peroxidase from Arabidopsis thaliana ${ }^{48}$ and horseradish ${ }^{49}$ showed just one invariant amino acid and COP showed no apparent similarities with other peroxidases, probably due to the presence of different genes for the peroxidase isoenzymes, which have been documented ${ }^{48,50}$. The amino acid composition of the purified COP is shown in Table 3.

Table 2. Comparison of the N-terminal sequence of peroxidases from plants

\begin{tabular}{lcllllllllllllll}
\hline Peroxidase & \multicolumn{11}{c}{ N-terminal amino acid sequence } \\
\hline COP $^{\mathrm{a}}$ & F & G & S & N & L & L & Q & N & K & N & R & F & A & I & N \\
Arbidopis $^{\mathrm{b}}$ & M & Q & L & N & A & T & F & Y & S & G & T & C & P & N & A \\
Soybeam $^{\mathrm{b}}$ & Q & L & T & P & T & F & Y & R & E & T & C & P & N & L & F \\
Barley $^{\mathrm{b}}$ & A & E & P & P & V & A & P & G & L & S & F & D & F & Y & W \\
HRP $^{\mathrm{c}}$ & A & A & S & I & I & R & L & H & F & H & D & C & F & & \\
HRP C1 $^{\text {d }}$ & E & L & T & P & T & F & J & D & N & S & C & P & M & V & S \\
\hline
\end{tabular}

${ }^{\mathrm{a}}$ From this study. ${ }^{\mathrm{b}} \mathrm{PDB}^{48}$. ${ }^{\mathrm{c}}$ Ref. 49 . ${ }^{\mathrm{d}}$ Ref. 50

Table 3. Amino acid (AA) composition of peroxidase from Copaifera langsdorffii leaves (COP)

\begin{tabular}{cccccc}
\hline & AA & Mol\% & & AA & Mol\% \\
\hline 1 & Asp & 7.20 & 10 & Tyr & 2.76 \\
2 & Glu & 8.51 & 11 & Val & 7.14 \\
3 & Ser & 9.75 & 12 & Met & 0.14 \\
4 & Gly & 14.49 & 13 & Cys & \\
5 & His & 0.72 & 14 & Ile & 3.65 \\
6 & Arg & 3.85 & 15 & Leu & 4.92 \\
7 & Thr & 3.78 & 16 & Phe & 17.62 \\
8 & Ala & 8.99 & 17 & Lys & 5.01 \\
9 & Pro & 1.18 & & & \\
\hline
\end{tabular}

\section{Effect of $\mathrm{pH}$ and temperature on COP activity}

The optimum reaction $\mathrm{pH}$ of the COP purified was between 5.0 and 7.0. The optimum reaction temperature was clearly between 30 and $40{ }^{\circ} \mathrm{C}$. The maximum activity was obtained at $\mathrm{pH} 6.0$ and 35 ${ }^{\circ} \mathrm{C}$. Our results are in accordance with Catalá and Chamarro ${ }^{51}$ and Wright and Nicell $^{52}$ for soybean peroxidase.

The stability of COP was evaluated after incubating the enzyme with different $\mathrm{pH}$ buffers, temperatures and incubation times. The results demonstrated that $\mathrm{COP}$ was stable over a wide range of $\mathrm{pH}$ and temperature values. The enzyme was stable between $\mathrm{pH} 4.5$ and 9.3 , in temperatures ranging from 7.7 to $50{ }^{\circ} \mathrm{C}$, up to a period of $24 \mathrm{~h}$. COP lost the activity after $6 \mathrm{~min}$ at $80{ }^{\circ} \mathrm{C}$. Under acidic conditions, loss of activity is considered to be due mainly to heme splitting from the enzyme, whilst at neutrality, the heme bond to the protein is stable, and activity is lost through chemical changes to the heme and through protein denaturation ${ }^{7}$. The changes in the thermostability of peroxidase may be due to the splitting of covalently bound neutral carbohydrates, but this effect had not yet been proven ${ }^{53}$. The $\beta$-secondary structure is considered to be the most stable form as well as the most heat stabile of the purified peroxidase preparations, since they contain a high content of hydroxyl amino acids ${ }^{39,54}$. COP has demonstrated catalytic ability similar to that of soybean peroxidase (SBP) over a wide range of temperatures and $\mathrm{pH}$ values ${ }^{52}$. SBP possesses a $\mathrm{pH}$ optimum at 6.4 
and maximum activity range of from $5.7-7.0$ and COP possesses a $\mathrm{pH}$ optimum at 6.0 , with a maximum activity ranged from 5.0 to 7.0. Both peroxidases were very stable at $25^{\circ} \mathrm{C}$ at neutral and alkaline $\mathrm{pH}$ values, but underwent rapid inactivation at acid $\mathrm{pH}$ (below 4.5 $)^{52}$. The purified COP showed similar stability and optimum $\mathrm{pH}$ value and temperature to those of the semi-purified enzyme (acetone powder). These results were confirmed by a statistical analysis using the Experimental Design.

In Brazil there are a great variety of plants that can be an inexhaustible source of enzymes which may be used in several areas, including analytical chemistry procedures, industry wastewater removal and as biosensors. There is a recent trend to use plant tissue or crude extract as an enzyme source. In this context, Copaifera langsdorffii seems to be an excellent source of stable peroxidase, which could be considered as an alternative to the use of HRP peroxidase.

\section{CONCLUSIONS}

Anionic peroxidase from Copaifera langsdorffii was obtained from leaves and purified by anion-exchange chromatography, FPLC and size-exclusion chromatography. The purified peroxidase has very similar molecular and structural properties to plant peroxidase studied previously, but was more active. COP presented activity similar to HRP peroxidase, higher turnover value than other plant peroxidases. The $\mathrm{COP}$ peroxidase was stable at a wide range of $\mathrm{pH}$ and temperature, which may be advantageous to its application as a biosensor or for the industrial wastewater treatment at a lower cost than other peroxidases such as horseradish peroxidase.

\section{ACKNOWLEDGMENTS}

We are grateful for the financial support from CAPES and from UNICAMP.

\section{REFERENCES}

1. Saunders, B. C. Em Inorganic Biochemistry; Eichhorn, G. L., ed.; Elsevier: Amsterdam, 1973, p. 988.

2. van Huystee, R. B.; Ann. Rev. Plant Physiol. 1987, 38, 205.

3. Ounigpipat, W.; Alexander, P. W.; Southwell-Keely, P. T.; Anal. Chim. Acta 1995, 309, 35

4. Robinson, D. S. Em Oxidative Enzymes in Food; Robinson, D. S.; Eskin, N. A. M., eds.; Elsevier Applied Science: New York, 1991.

5. Bruemmer, J. H.; Roe, B.; Bowen, E. R.; J. Food Sci. 1976, 41, 186.

6. Floris, G.; Medda, R.; Rinaldi, A.; Phytochemistry 1984, 23, 1527.

7. Adams, J. B.; Food Chem. 1997, 60, 201.

8. Shannon, I. M.; Kay, E.; Lew, J. Y.; J. Biol. Chem. 1996, 241, 2166.

9. Vamos-Vigyaz, L.; CRC Crit. Rev. Food Sci. Nutr. 1991, 15, 49.

10. Burnette, F. S.; J. Food Sci. 1977, 42, 1.

11. Yamamoto, H. Y.; Steinberg, M. P., Nelson, A. I.; J. Food Sci. 1962, 27, 113.
12. Clochard, A.; Guern, J.; Rev. Gen. Froid, 1973, 64, 860.

13. Servant, I.; Gilbert, H.; Gilot, B.; J. Food Eng. 1986, 5, 301.

14. Azevedo, A. M.; Martins, V. C.; Prazeres, D. M.; Vojinovic, V.; Cabral, J. M.; Fonseca, L. P.; Biotechnol. Annu. Rev. 2003, 9, 199.

15. Matheis, G.; Whitaker, J. R.; J. Food Biochem. 1984, 8, 137.

16. Matheis, G.; Whitaker, J. R.; J. Food Biochem. 1987, 11, 309.

17. Sergeyeva, T. A.; Lavrik, N.; Rachkov, A. E.; Anal. Chim. Acta 1999, 391, 289.

18. Kokçam, I.; Naziroglu, M.; Clin. Chim. Acta 1999, 289, 23.

19. Halliwell, B.; Chirico, S.; Am. J. Clin. Nutr. 1993, 57, 715S.

20. Kanner, J.; Meat Sci. 1994, 36, 169.

21. Medeiros, M. H. G.; Loureiro, A. P. M.; Carvalho, V. M.; Rev. Med. 1996, $75,16$.

22. Wright, H.; Nicell, A.; Bioresour. Technol. 1999, 70, 69.

23. Ikehata, K.; Buchanan, I. D.; Pickard, M. A.; Smith, D. W.; Bioresour. Technol. 2005, 96, 1758 .

24. Driessel, B. V.; Christov, L.; J. Biosci. Bioeng. 2001, 92, 271.

25. Martinez, A. T.; Speranza, M.; Ruiz-Duenas, F. J.; Ferreira, P.; Camarero, S.; Guillen, F.; Martinez, M. J.; Gutierrez, A.; del Rio, J. C.; Int. Microbiol. 2005, 8, 195 .

26. Caruso, C. S.; Vieira, I. C.; Fatibello-Filho, O.; Anal. Lett. 1999, 32, 39.

27. Vieira, I. C.; Lupetti, K. O.; Fatibello-Filho, O.; Quim. Nova 2003, 26, 39.

28. Hofrichter, M.; Scheibne, R. K.; Schneegass, I.; Fritsche, W.; Appl. Environ. Microbiol. 1998, 64, 399.

29. Liu, Y. L.; Yang, Y. H.; Yang, H. F.; Liu, Z. M.; Shen, G. L.; Yu, R. Q.; J. Inorg. Biochem. 2005, 99, 2046.

30. Konash, A.; Magner, E.; Biosens. Bioelectron. 2006, 22, 116.

31. Lee, Y. M.; Kwon, O. Y.; Yoon, Y. J.; Ryu, K.; Biotechnol. Lett. 2006, 28, 39.

32. Xu, Q.; Mao, C.; Liu, N. N.; Zhu, J. J.; Sheng, J.; Biosens. Bioelectron. 2006, 22, 768

33. Zwirtes de Oliveira, I. R.; Fernandes, S. C.; Vieira, I. C.; J. Pharm. Biomed. Anal. 2006, 41, 366.

34. Veiga Jr., V. F.; Pinto, A. C.; Quim. Nova 2002, 25, 273.

35. Jackson, P.; Ricardo, C. P. P.; Anal. Biochem. 1992, 200, 36.

36. Khan, A. A.; Robinson, D. S.; Food Chem. 1994, 49, 407.

37. Davis, B. J.; Ann. New York Acad. Sci. 1964/65, 121, 404.

38. Gove, J. P.; Hoyle, M. C.; Plant Physiol. 1975, 56, 684

39. Laemmli, U. K.; Nature 1970, 227, 680.

40. Lowry, O. H.; Rosebrough, N. J.; Farr, A. L.; J. Biol. Chem. 1951, 193, 265.

41. Leatherbarrow, R. J.; Grafit. Version 3.0; Erithacus software Ltda; Staines, UK, 1992.

42. Shimoni, M.; Reuveni, R.; J. Chromatogr. 1993, 646, 99.

43. Civello, P. M.; Martinez, G. A.; Chaves, A. R.; J. Agric. Food Chem. 1995, $43,2596$.

44. López-Serrano, M.; Ros-Barceló, A.; Food Chem. 1996, 55, 133.

45. Kristensen, B. K.; Bloch, H.; Rasmussen, S. K.; Plant Physiol. 1999, 120, 501

46. Liao, X.-R.; Zhu, X.-C.; He, P.-C.; Phytochemistry 1999, 51, 143.

47. Holschuh, H. J.; Tese de Doutorado; Universidade Estadual de Campinas, Brasil, 2000.

48. http://www.rcsb.org/pdb, PDB-Protein data basis, acessada em Novembro 2005.

49. Welinder, K. G.; FEBS Lett. 1976, 72, 19.

50. Welinder, K. G.; Eur. J. Biochem. 1979, 96, 483.

51. Catalá, C. Y.; Chamarro, J.; Rev. Agroquím. Tecnol. Alim. 1987, 27, 509.

52. Wright, H.; Nicell, A.; Bioresour. Technol. 1999, 70, 69.

53. Clemente, E.; Phytochemistry 1998, 49, 29.

54. Tamura, Y.; Morita, Y.; J. Biochem. 1975, 78, 561. 